\title{
Medium effects on micropropagation and genetic stability of Citrullus lanatus oleaginous type
}

\author{
Yah Gwladys Gnamien ${ }^{1,2^{*}}$, Irié Arsène Zoro $\mathrm{Bi}^{1}$, Yatty Justin Kouadio ${ }^{1}$, Yves Brostaux ${ }^{3}$, \\ Jean-Pierre Baudoin ${ }^{2}$

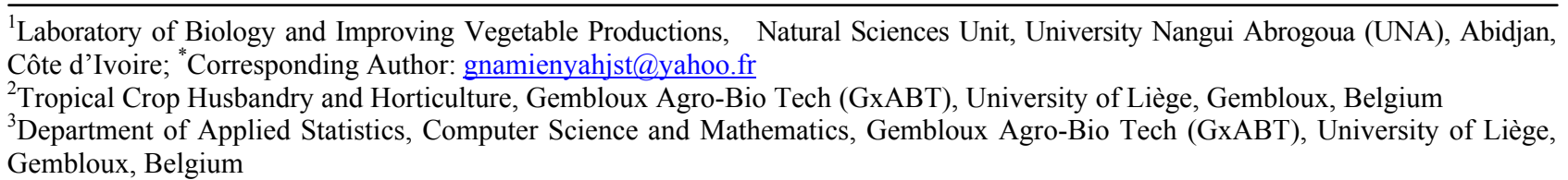

Received 29 April 2013; revised 23 May 2013; accepted 17 June 2013

Copyright (C) 2013 Yah Gwladys Gnamien et al. This is an open access article distributed under the Creative Commons Attribution License, which permits unrestricted use, distribution, and reproduction in any medium, provided the original work is properly cited.

\section{ABSTRACT}

To regenerate adventitious shoots from the cotyledon proximal parts of Citrullus lanatus (Thunb.) Matsum. and Nakai ssp. mucosospermus (Fursa) oleaginous type, different concentrations of MS mineral elements, sucrose, 6-benzylaminopurine (BAP) and agar were tested. Shoot induction proved to depend on the interaction between levels of sucrose, BAP and MS mineral elements in the medium. The medium containing $3 / 2$ strength of MS mineral elements, $35 \mathrm{~g} / \mathrm{l}$ sucrose and $1 \mathrm{mg} / \mathrm{l}$ BAP solidified with $6 \mathrm{~g} / \mathrm{l}$ agar allowed the production of numerous shoots without a callus phase. After 3 weeks of culture, $76.7 \%$ of the cotyledon proximal parts induced shoots with an average of 12.26 shoots per explant and a mean shoot length of $17.13 \mathrm{~mm}$. The induced shoots were directly rooted and thus complete plants ready for acclimatization were obtained using a two steps procedure. Depending on the genotype, the shoot induction from cotyledon proximal parts ranged from $54 \%$ to $96 \%$. Rooted plantlets were acclimatized and transferred to field, where they grew well, developed flowers and fruits like seeded plants. The assessment of the genetic stability of the in-vitro-regenerated plantlets by means of an Amplified Fragment Length Polymorphism (AFLP) analysis with the combination of 5 primers revealed no differences between regenerated plantlets and mother plants.

Keywords: AFLP; Genetic Stability; In Vitro; Oleaginous Seeds; Organogenesis

\section{INTRODUCTION}

Citrullus lanatus (Thunb.) Matsum. and Nakai ssp. mucosospermus (Fursa) oleaginous type and other species of the Cucurbitaceae family are grown mainly for their seeds which constitute an important component of the diet in many African (Nigeria, Benin, Ghana, Cameroun, Congo, Namibia, Sierra Leone and Côte d'Ivoire) and Asian countries [1-4]. In sub-Saharan Africa, the cucurbit oleaginous type species are prized for their oleaginous seeds consumed as thickeners of a traditional soup called egussi soup in Nigeria, Benin, Cameroon and Congo [1,5], and pistachio soup in Côte d'Ivoire $[2,4]$. The $C$. lanatus oleaginous type species cultivated in Côte d'Ivoire is subdivided into two different cultigroups on the basis of the seed size. The first cultigroup (wlèwlè), containing three cultivars, has smooth seeds that are tapered to the point of attachment. The seeds of the second cultigroup (bebou), containing one cultivar, are ovoid and flattened, with a thickened and roughened margin $[2,6]$. The seeds of oleaginous cucurbits are reported to be rich in nutrients including $60 \%$ of lipids and $30 \%$ of proteins $[7,8]$. The oil obtained from these seeds is easily refined and often preferred to other oils for cooking [9].

The oleaginous cucurbits are generally important as a cover crop in the intercropping farming or farm systems $[6,10]$. Like other neglected and underutilized crops in Africa, the oleaginous cucurbits have numerous agronomic and economic potentials. Their seeds are sold in rural and urban marketplaces [4,11]. Traditionally the cucurbits of oleaginous type were regarded as a woman's plant and cultivated mostly in home gardens but today their total acreage is steadily increasing [12]. However, it is only very recently that research programs began to focus their interest on these plants $[4,13]$ in order to address the challenges that producers are faced with: pest 
attacks, low yields and poor post-harvest conservation $[14,15]$. The fruits of cucurbits oleaginous type are generally harvested after complete senescence of the plants. Because of the fruiting extent, all the fruits do not reach maturity before plant senescence, resulting in a mixing of mature and immature seeds at the harvest [16]. Nerson [17] reported that the seeds of cucurbit species extracted from immature or over-mature fruits have a low germination, and yet multiplication of the cucurbits is mainly carried out through botanical seeds. In addition, seeds loose quickly their germinating capacity depending upon precise timing of the mature fruit harvest, mode of seed extraction and storage practices [15-17]. Also, due to their cross-pollinating breeding system the maintenance of initial genotypes is a major problem $[4,15,18]$.

Increasing the use and the production of these cucurbits can improve food security and diversify small farmer's income [4]. In this endeavor the development of micropropagation protocols will offer an easy and economic alternative for the rapid multiplication of elite improved cultivars and the conservation and distribution of genetic resources of Citrullus lanatus oleaginous type.

Most of the protocols developed for the micropropagation of the Cucurbitaceae species are carried out in more than two phases $[19,20]$, e.g., a bud induction phase with/or a multiplication phase, an elongation phase, and a rooting phase. However, this approach is time consuming, expensive and sometimes yields a low rate of shoot induction. The purpose of this study is to develop for the C. lanatus oleaginous type a two-phase micropropagation protocol that is fast, efficient and highly reproducible. Effects of plant growth regulators, as well as levels of nutrient medium, sucrose and agar were assessed.

Since phenotypic and genetic variations are reported to occur as a consequence of the propagation process, it is particularly important to assess the genetic stability of the cucurbits regenerants before their establishment in the field. So, the genetic stability of the in vitro plants regenerated was assessed by an AFLP analysis, a technique proven to be a highly efficient tool for characterizing somaclonal variation $[21,22]$.

\section{MATERIAL AND METHODES}

\subsection{Plant Material}

Mature seeds of the two different cultigroups of $C$. lanatus (Thunb.) Maktum and Nakai ssp. Mucosospermus (Fursa) oleaginous type, involving four cultivars, were used as explants source (Figures 1(a)-(d)). These cultivars were previously identified by Zoro et al. [6]. The three cultivars of the first cultigroup (wlèwlè) were designated as follows: CL for cultivar with large seeds (average of $120 \mathrm{~mm}^{2}$ ), CM for cultivar with medium seeds (average of $59 \mathrm{~mm}^{2}$ ) and CS for cultivar with small

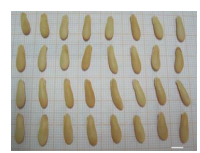

(a)

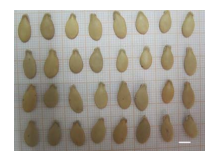

(b)

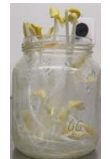

(e)

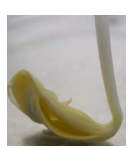

(f)

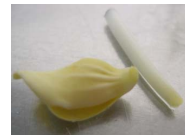

(g)

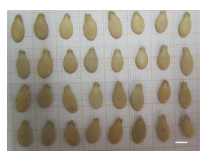

(c)

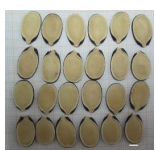

(d)

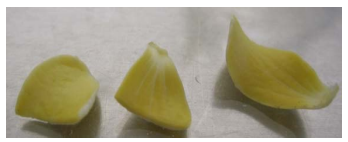

(h)
Figure 1. Seeds of four cultivars of C. lanatus oleaginous type and different stages of explants sampling: (a) Small seeds (CS); (b) Medium seeds (CM); (c) Large seeds (CL); (d) Thickened margin seeds (CT); (e) In vitro plantlets in germination medium; (f) Closed cotyledons with hypocotyl attached; (g) Separate hypocotyl of the closed cotyledons; (h) Separate and cut in half cotyledons (from left to right: distal part, proximal part and entire cotyledon). Bars represent 5 $\mathrm{mm}$.

seeds (average of $42 \mathrm{~mm}^{2}$ ). The only cultivar of the second cultigroup (bebou) with thickened margin seeds (average of $179 \mathrm{~mm}^{2}$ ) is designated as CT. All these cultivars were selected from a germplasm collection at the University Nangui Abrogoua (UNA) Abidjan, Côte d'Ivoire.

\subsection{Explant Preparation}

Seed-coats were removed manually and the embryos surface sterilized during $25 \mathrm{~min}$ in a $1.6 \%$ sodium hypochlorite with one drop of Tween 20. After sterilisation, seeds were rinsed six times with sterile distilled water and sown in culture flasks containing $20 \mathrm{ml}$ of hormonefree MS basal medium [23] solidified with $8 \mathrm{~g} / 1$ agar (Invitrogen select agar). The $\mathrm{pH}$ of the medium was adjusted to 5.7 before the agar was added. The medium was then autoclaved at $121^{\circ} \mathrm{C}$ for $20 \mathrm{~min}$. The seeds were incubated in the dark during the five days of germination at $28^{\circ} \mathrm{C} \pm 2{ }^{\circ} \mathrm{C}$. Cotyledonary explants were removed from 5-day-old seedlings as follows: the hypocotyl was first cut off close to the cotyledons; the cotyledons were then cut in half resulting in a proximal and a distal part (Figures 1(e)-(h)). Subsequently, proximal parts of the cotyledons with hypocotyls segment were separated with the help of a scalpel blade. The apical bud of the seedling was carefully removed resulting in a cotyledon proximal part with the hypocotyl segment explants [2].

\subsection{Culture Establishment}

The reference culture medium used in all the experiments is the MS basal medium [23]. The $\mathrm{pH}$ of the media was adjusted to 5.7 with $1 \mathrm{~N} \mathrm{NaOH}$ or $1 \mathrm{~N} \mathrm{HCl}$ before autoclaving at $121^{\circ} \mathrm{C}$ for $20 \mathrm{~min}$. All the cultures were incubated under $50 \mathrm{~mol} / \mathrm{m}^{2} / \mathrm{s}$ light provided by cool 
white fluorescent lamps for a photoperiod of $12 \mathrm{~h}$ at $28^{\circ} \mathrm{C} \pm 2^{\circ} \mathrm{C}$.

To determine the optimal media for the direct shoot induction, two experiments were carried out.

The first consisted of studying the effects of various concentrations of the plant growth regulator 6-benzylaminopurine (BAP) $(0.25,0.5,0.75,1 \mathrm{mg} / \mathrm{l})$, different strengths of MS mineral elements (1/4 MS; $1 / 2 \mathrm{MS}$; full strength MS and 2 MS), various amounts of sucrose (20, $25,30,35,40 \mathrm{~g} / \mathrm{l})$ and Invitrogen select agar $(5,6,7,8$ $\mathrm{g} / \mathrm{l})$ on shoot induction. From previous trials [2], the full strength MS medium with $1 \mathrm{mg} / \mathrm{l} \mathrm{BAP}, 30 \mathrm{~g} / 1$ sucrose and $8 \mathrm{~g} / \mathrm{l}$ agar was used as a control. Explants were cultured in $55 \mathrm{~mm} \times 70 \mathrm{~mm}$ culture flasks, each containing $25 \mathrm{ml}$ of medium. Except for the sucrose-effect test which consisted of twenty replicates, each media combination consisted of ten replicates. One replicate consists of one flask with five explants. After three weeks of culture on media, explants were scored for shoot induction, number of shoots and shoot length.

Once the concentrations of BAP, MS mineral elements, sucrose and agar influencing shoot induction were identified, they were used in combinations on medium for optimizing shoot induction. In this second set of experiments, the effects of the significant factors were assessed by combining the optimal concentrations. The cotyledon proximal part explants were cultured on three different strengths of MS mineral elements (3/2 MS, 2 MS and 5/2 MS) combined each with three concentrations of sucrose $(20,27.5$ and $35 \mathrm{~g} / \mathrm{l})$ and $\operatorname{BAP}(0.5,0.75$ and $1 \mathrm{mg} / \mathrm{l})$ using a Box-Benhken design [24]. As a consequence, a total of 13 combinations of culture media were studied (Table 1). The thirteen culture media were replicated monthly three times in two plates, with two flasks per plate and five explants per flask. Finally a fourteenth culture medium, corresponding to the optimal composition based on the results of the second set of experiments was tested to confirm the results obtained. After three weeks of culture on the media, the explants were scored for shoot induction, number of shoots and shoot length.

\subsection{Genotypic Response}

Once the optimal medium composition for shoot induction was identified, the genotypic influence was investigated. This experiment was performed with the four genotypes CL, CM, CS and CT. Each genotype consisted of ten replicates. One replicate consists of one flask with five explants. After three weeks of culture the explants were scored for shoot induction, number of shoots and shoot length.

\subsection{Rooting and Acclimatization}

Shoots harvested from induction phase were placed in
Table 1. Combination of thirteen media for shoots induction according to Box-Benhken design.

\begin{tabular}{ccccc}
\hline Media & MS minerals & Sucrose $(\mathrm{g})$ & BAP $(\mathrm{mg} / \mathrm{l})$ & Agar $(\mathrm{g})$ \\
\hline M1 & $3 / 2 \mathrm{MS}$ & 27.5 & 0.5 & 6 \\
M2 & $3 / 2 \mathrm{MS}$ & 27.5 & 1 & 6 \\
M3 & $3 / 2 \mathrm{MS}$ & 35 & 0.75 & 6 \\
M4 & $3 / 2 \mathrm{MS}$ & 20 & 0.75 & 6 \\
M5 & $2 \mathrm{MS}$ & 35 & 1 & 6 \\
M6 & $2 \mathrm{MS}$ & 20 & 1 & 6 \\
M7 & $2 \mathrm{MS}$ & 20 & 0.5 & 6 \\
M8 & $2 \mathrm{MS}$ & 35 & 0.5 & 6 \\
M9 & $2 \mathrm{MS}$ & 27.5 & 0.75 & 6 \\
M10 & $5 / 2 \mathrm{MS}$ & 27.5 & 0.5 & 6 \\
M11 & $5 / 2 \mathrm{MS}$ & 27.5 & 1 & 6 \\
M12 & $5 / 2 \mathrm{MS}$ & 35 & 0.75 & 6 \\
M13 & $5 / 2 \mathrm{MS}$ & 20 & 0.75 & 6 \\
\hline
\end{tabular}

$150 \mathrm{~mm} \times 20 \mathrm{~mm}$ culture tubes containing $15 \mathrm{ml}$ of rooting medium (MS hormone-free medium containing 30 $\mathrm{g} / 1$ sucrose and solidified with $6 \mathrm{~g} / \mathrm{l}$ agar). The incubation conditions and light intensity were the same as stated above. After two weeks on the rooting medium, the number of rooted plantlets was recorded. Rooted plantlets were transferred to pots containing autoclaved soil $[80 \%$ of Klasmann ${ }^{\circledR} 4$ Special No. $26,15 \%$ peat, $5 \%$ of the Rhine sand and organic fertilizer $(0.6 \mathrm{~g} / 1$ mixture $)]$ for acclimatization in greenhouse. The details of acclimatization procedures were described by Gnamien et al. [2]. Plantlets that survived acclimatization were counted three weeks after transfer to the greenhouse.

\subsection{Morphologique Evaluation}

The study was carried out in Abidjan district from November 2010 to January 2011. The study site was located in the experimental farm of University Nangui Abrogoua (UNA) Abidjan, Côte d'Ivoire, between latitudes $5^{\circ} 17^{\prime} \mathrm{N}-5^{\circ} 31^{\prime} \mathrm{N}$ and longitudes $3^{\circ} 45^{\prime} \mathrm{W}-4^{\circ} 22^{\prime} \mathrm{W}$. In this zone, rainfalls are abundant (annual mean $>2000$ $\mathrm{mm}$ ) and the mean temperature is $28^{\circ} \mathrm{C}$, with annual amplitude of $5^{\circ} \mathrm{C}-10^{\circ} \mathrm{C}$. The acclimatized plantlets were transferred to field in order to observe their growth and development. Manual weeding was carried out during plant development. Morphological characterization of the micropropagated plants was compared with the seedpropagated plants, using standard descriptors for cucurbits: eight characters (Table 2) were chosen among those published for Lagenaria siceraria [25]. 
Table 2. List of descriptors for characterization of C. lanatus plants obtained from in vitro culture and seed.

\begin{tabular}{cccc}
\hline Characters & codes & Type and period of observation & Sample size (n) \\
\hline Male flowering time $(\mathrm{days})^{\mathrm{a}}$ & MF & Number of days from sowing to first male flower opening per plant & 5 \\
Female flowering time $(\mathrm{days})^{\mathrm{a}}$ & FF & Number of days from sowing to first female flower opening per plant & 5 \\
Male flower diameter $(\mathrm{cm})^{\mathrm{b}}$ & MFD & Diameter of petals, measured at flower opening & 30 \\
Female flower diameter $(\mathrm{cm})^{\mathrm{b}}$ & FFD & Diameter of petals, measured at flower opening & 30 \\
Male flower peduncle length $(\mathrm{cm})^{\mathrm{b}}$ & MFPL & Peduncle length, measured at flower opening & 30 \\
Female flower peduncle length $(\mathrm{cm})^{\mathrm{b}}$ & FFPL & Peduncle length, measured at flower opening & 30 \\
Limb length $(\mathrm{cm})^{\mathrm{b}}$ & LL & Limb length, measured after formation of the first fruit & 30 \\
Limb width $(\mathrm{cm})^{\mathrm{b}}$ & LWI & Limb width, measured after formation of the first fruit & 30 \\
\hline
\end{tabular}

${ }^{\mathrm{a}}$ Measurement on each plant type per cultivar; ${ }^{\mathrm{b}}$ Measurement on six organs per plant.

\subsection{Genetic Stability Assessment}

Following culture on root-inducing medium, leaves of regenerated plants were excised, and the stored roots of mother plant were grounded individually using an MM300 mixer mill (Qiagen) and DNA was isolated using the MATAB (mixed alkyltrimethylammonium bromide) method [26]. DNA concentration was estimated by Full-spectrum UV/VIS spectrophotometer (NanoDrop, ND-1000), and was diluted with sterile distilled water to give a final concentration of $250 \mathrm{ng} \cdot \mu \mathrm{l}^{-1}$.

The AFLP procedure was carried out using the AFLP Core Reagent Kit and AFLP Primer Kit (Invitrogen Life Technologies, California) following the manufacturer's protocol. A total of five primers i.e., $\mathrm{E}_{\mathrm{AAC}}-\mathrm{M}_{\mathrm{CAG}}, \mathrm{E}_{\mathrm{AAG}^{-}}$ $\mathrm{M}_{\mathrm{CAG}}, \mathrm{E}_{\mathrm{AAG}}-\mathrm{M}_{\mathrm{CAT}}, \mathrm{E}_{\mathrm{AAG}}-\mathrm{M}_{\mathrm{CTC}}$ and $\mathrm{E}_{\mathrm{AAC}}-\mathrm{M}_{\mathrm{CAA}}$ were used to amplify the DNA.

Template DNA (250 ng) was double digested with 2.5 units of each EcoRI and MseI restriction enzymes for $2 \mathrm{~h}$ at $37^{\circ} \mathrm{C}$ in a final volume of $25 \mu \mathrm{l}$. The mixture was incubated for $15 \mathrm{~min}$ at $70^{\circ} \mathrm{C}$ to inactivate the restriction endonucleases. Specific adapters were ligated to the restriction fragments with 1 unit of T4 DNA ligase in 10 $\mathrm{mM}$ Tris- $\mathrm{HCl}(\mathrm{pH} 7.5), 10 \mathrm{mM} \mathrm{Mg}$ acetate, $50 \mathrm{mM}$ $\mathrm{K}$-acetate and $0.4 \mathrm{mM}$ ATP at $20^{\circ} \mathrm{C} \pm 2{ }^{\circ} \mathrm{C}$ for $2 \mathrm{~h}$. Pre-amplification was carried out using pre-amp primer mix, 10X PCR buffer and Taq DNA polymerase, under the following conditions: 20 cycles of $94^{\circ} \mathrm{C}$ for $30 \mathrm{~s}, 56^{\circ} \mathrm{C}$ for $60 \mathrm{~s}$ and $72^{\circ} \mathrm{C}$ for $60 \mathrm{~s}$. Further selective amplification was performed, using the EcoRI +3 (three selective bases) and MseI + 3 (three selective bases) primers. Amplifications were carried out using a touch-down PCR program: 1 cycle of $94^{\circ} \mathrm{C}$ for $30 \mathrm{~s}, 65^{\circ} \mathrm{C}$ for $30 \mathrm{~s}$, and $72^{\circ} \mathrm{C}$ for $60 \mathrm{~s}$, then 13 cycles with the annealing temperature lowered by $0.7^{\circ} \mathrm{C}$ per cycle, followed by $23 \mathrm{cy}$ cles of $94^{\circ} \mathrm{C}$ for $30 \mathrm{~s}, 56^{\circ} \mathrm{C}$ for $30 \mathrm{~s}$, and $72^{\circ} \mathrm{C}$ for $60 \mathrm{~s}$. All PCR amplifications were performed using a PTC200 thermal cycler (Peltier Thermal Cycler, MJ Research).
AFLP products were resolved in denaturing $6 \%$ polyacrylamide gels in $1 \times$ TBE buffer as follows: the amplified DNAs were mixed with $20 \mu \mathrm{l}$ of formamide dye (98\% formamide, $10 \mathrm{mM}$ EDTA $\mathrm{pH} 8.0,1 \%$ xylene cyanol and $1 \%$ bromophenol blue) before denaturation by heating for $3 \mathrm{~min}$ at $90^{\circ} \mathrm{C}$. Five microliters of each denaturated DNA mixture were loaded onto a pre-warmed polyacrylamide gel. Electrophoresis was performed at $1800 \mathrm{~V}$ for $1 \mathrm{~h}$ and the separated DNA bands were visualized by silver staining [27]. The gels were then dried overnight and photographed.

\subsection{Experimental Design, Data Collection and Statistical Analysis}

The first experiment was arranged in a completely randomised design. The effects of different media were evaluated by a standard analysis of variance (ANOVA). When the null hypothesis was rejected, means were compared using Tukey's multiple range test at 5\% level of significance [28]. Data were processed using the software Minitab $^{\circledR}$ for Windows, version 15.00.

The second set of experiment was run as a BoxBenhken design in order to reduce the number of tested culture media. Since a great number of explants did not show any shoot growth, the optimization of shoot induction was determined on the basis of the mean percentage of explants inducing at least one shoot. This percentage was calculated for the five explants on each flask and arcsin-transformed before statistical analysis for a better compliance with the statistical requirement of the further analysis.

The arcsin-percentages were then analysed by a full quadratic response surface model (linear, quadratic and first-order interaction terms) of the three tested factors (MS mineral elements, sucrose and BAP) and the nonsignificant terms were backward eliminated to obtain the simplest adjusted model to the experimental data. Prior 
to this analysis, factors levels were coded by $-1,0$ and +1 , for respectively low, medium and high concentrations. This model was used to draw contour plots of the response variable and estimate the optimal composition of the culture media.

For morphological evaluation, the field lay out was a completely randomized design, with two plots per cultivar, one plot respectively for micropropagated and seedpropagated plants. Control plants were grown from seeds [29]. Each cultivar was represented by 10 plants. The planting distance was $3 \mathrm{~m}$ between and within rows with $1.5 \mathrm{~m}$ of edges. Two consecutive plots were spaced by 3 m. Morphological evaluation was compared between the micropropagated and seed-propagated plants for each cultivar by an analysis of variance.

AFLP markers were scored for presence (1) or absence $(0)$, and then entered into a binary matrix representing the AFLP profile of each sample.

\section{RESULTS AND DISCUSSION}

\subsection{Effects of Mineral Concentration}

The various mineral concentrations had significant effects on shoot induction (Table 3). The 1/2 MS and 2 MS

Table 3. Effect of mineral, BAP, sucrose and agar concentrations on shoot induction for four cultivars of C. lanatus oleaginous type. Cotyledon proximal part with hypocotyl segment obtained from 5-day-old seedlings was cultured onto shoot induction medium. Data represented as mean $\pm \mathrm{SE}$.

\begin{tabular}{|c|c|c|c|}
\hline Factor & Percentage of shoot induction (\%) & Number of shoots per explant & Shoot length (mm) \\
\hline \multicolumn{4}{|c|}{ Mineral concentration } \\
\hline $1 / 4 \mathrm{MS}$ & 24 & $2.00 \pm 0.91^{\mathrm{a}}$ & $10.05 \pm 3.22^{\mathrm{a}}$ \\
\hline $1 / 2 \mathrm{MS}$ & 64 & $3.86 \pm 1.62^{\mathrm{b}}$ & $9.19 \pm 2.52^{\mathrm{a}}$ \\
\hline MS & 20 & $4.30 \pm 1.77^{\mathrm{b}}$ & $11.31 \pm 2.40^{\mathrm{a}}$ \\
\hline $2 \mathrm{MS}$ & 54 & $8.63 \pm 3.33^{\mathrm{c}}$ & $14.17 \pm 3.91^{\mathrm{b}}$ \\
\hline \multicolumn{4}{|c|}{ BAP concentration (mg/l) } \\
\hline 0.25 & 62 & $6.19 \pm 3.02$ & $13.61 \pm 4.92$ \\
\hline 0.50 & 40 & $3.75 \pm 1.89$ & $14.40 \pm 4.56$ \\
\hline 0.75 & 58 & $5.69 \pm 2.58$ & $15.16 \pm 4.02$ \\
\hline 1 & 46 & $5.17 \pm 2.50$ & $12.83 \pm 3.51$ \\
\hline \multicolumn{4}{|c|}{ Sucrose concentration (g/l) } \\
\hline 20 & 89 & $4.12 \pm 1.69^{\mathrm{a}}$ & $15.90 \pm 7.95$ \\
\hline 25 & 87 & $6.61 \pm 3.55^{\mathrm{b}}$ & $16.74 \pm 7.66$ \\
\hline 30 & 87 & $5.17 \pm 2.45^{\mathrm{c}}$ & $17.25 \pm 5.90$ \\
\hline 35 & 86 & $5.06 \pm 2.49^{\mathrm{c}}$ & $15.14 \pm 6.45$ \\
\hline 40 & 82 & $5.27 \pm 2.96^{\mathrm{c}}$ & $13.64 \pm 5.61$ \\
\hline \multicolumn{4}{|c|}{ Agar concentration (g/l) } \\
\hline 5 & 70 & $5.09 \pm 2.31$ & $21.49 \pm 6.15$ \\
\hline 6 & 92 & $4.44 \pm 2.53$ & $21.58 \pm 6.86$ \\
\hline 7 & 92 & $5.11 \pm 2.33$ & $18.13 \pm 3.99$ \\
\hline 8 & 92 & $5.80 \pm 2.66$ & $13.16 \pm 2.52$ \\
\hline \multicolumn{4}{|l|}{ Genotype } \\
\hline $\mathrm{CS}$ & 96 & $12.44 \pm 6.3^{\mathrm{a}}$ & $16.89 \pm 5.4$ \\
\hline $\mathrm{CM}$ & 76.7 & $12.26 \pm 6.71^{\mathrm{a}}$ & $17.59 \pm 4.01$ \\
\hline $\mathrm{CL}$ & 54 & $11.93 \pm 4.91^{\mathrm{a}}$ & $18.47 \pm 5.43$ \\
\hline $\mathrm{CT}$ & 68 & $5.03 \pm 2.86^{\mathrm{b}}$ & $20.94 \pm 5.83$ \\
\hline
\end{tabular}

For genotypic response explants were cultured onto 3/2 strength of MS medium supplemented with $35 \mathrm{~g} / 1 \mathrm{sucrose}, 1 \mathrm{mg} / 1 \mathrm{BAP}$ and $6 \mathrm{~g} / 1$ agar. Means in a column followed by a common letter are not significantly different at the $5 \%$ level (Tukey's multiple range test). 
gave more explants inducing shoots compared to $1 / 4$ and full-strength MS. The ANOVA revealed a very highly significant difference in the number and length of shoots induced by various concentrations of MS mineral elements $\left(F_{3,57}=28.73, \mathrm{P}<0.001, \mathrm{~F}_{3,57}=8.97, \mathrm{P}<0.001\right.$, respectively for number and length of shoots). The highest shoot induction was obtained on double-strength MS mineral elements. In addition, the shoots from doublestrength MS were stout, healthy and green (Figure 2(a)). In contrast, on 1/4 MS mineral elements, the shoots were short thin, with small narrow leaves (Figure 2(b)). An increase in the MS minerals concentration to $2 \mathrm{MS}$ doubled the number of induced shoots compared to full strength MS (Table 3). Similar observations had also been reported in pumpkin (Cucurbita moschata Duch.) by Zhang et al. [30] who investigated the effect of various MS strength on root formation. They noted that pumpkin elongated shoots were rooted more easily on 2 MS than on $2 / 3$ MS and 1/2 MS. Similarly to shoots induction, the root formation decrease when MS strength declined.

\subsection{Effects of 6-Benzylaminopurine (BAP) Concentration}

The percentage of shoot induction was influenced by BAP concentrations (Table 3). However, no significant difference in both the number and the length of induced shoots was noted between different concentrations of $\operatorname{BAP}\left(\mathrm{F}_{3,64}=2.08, \mathrm{P}=0.117, \mathrm{~F}_{3,64}=1.45, \mathrm{P}=0.240\right.$, respectively for number and length of shoots). Similar results were found by Canli and Tian [31] in Prunus salicina Lind1. In contrast, Thomas and Sreejesh [32], and Huq et al. [33] working respectively on ash gourd
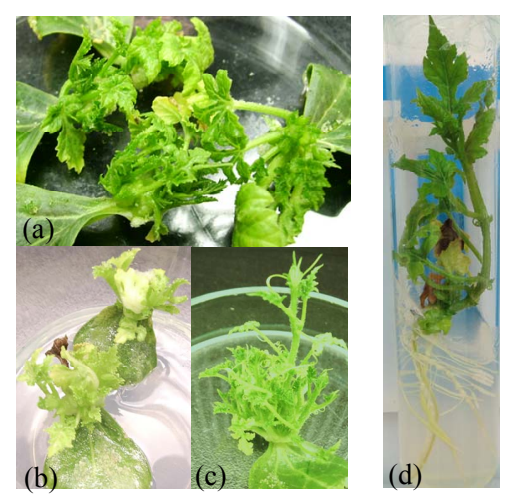

Figure 2. Plantlet micropropagation from cotyledonary explants of C. lanatus oleaginous type. (a) Adventitious shoot induction on 2 MS medium; (b) Adventitious shoot induction on $1 / 4$ MS medium; (c) Multiple shoot induction on optimal medium; (d) Rooting of shoot on growth regulator free MS medium.
(Benincasa hispida L.) and pointed gourd (Trichosanthes dioica Roxb.) noticed the variation in shoot induction and plant micropropagation according to BAP concentrations. Nevertheless, when the number of shoots on each explant was analyzed (before calculating the means number of shoots per explant), it was noticed that some explants on media containing BAP concentrations between 0.5 and $1 \mathrm{mg} / 1$ showed sometimes a high number of shoots. Therefore, the same concentration range was retained in the subsequent experiments.

\subsection{Effects of Sucrose Concentration}

The percentage of shoot induction decreased with the increase of sucrose concentration (Table 3). But, higher concentrations of sucrose favoured higher number of shoots per explant. The ANOVA revealed a very highly significant difference in the number of shoots per explant between the different concentrations of sucrose $\left(\mathrm{F}_{4,341}=\right.$ 3.49; $\mathrm{P}=0.011)$. No significant difference of shoot length was noted between different concentrations of sucrose $\left(\mathrm{F}_{4,341}=1.72, \mathrm{P}=0.131\right)$. The sucrose concentration of $25 \mathrm{~g} / 1$ promoted the highest number of shoots per explant. The sucrose concentration of $20 \mathrm{~g} / \mathrm{l}$, on the contrary, gave the lowest number of shoots per explant. Similar results are reported in cucumber (Cucumis sati$v u s)$ for which high concentration of sucrose $(0.25$ or $0.50 \mathrm{M}$ ) could enhance germination of somatic embryos [34]. However, when the number of shoots per explant was analyzed, it was observed that a sucrose concentrations varying between 25 and $40 \mathrm{~g} / 1$ could give higher number of shoots. Therefore, the same concentration range was retained in the subsequent experiments.

\subsection{Effects of Agar Concentration}

The percentage of shoot induction was higher for the media solidified with 6,7 , and $8 \mathrm{~g} / 1$ agar compared to medium solidified with $5 \mathrm{~g} / \mathrm{l}$ agar (Table 3 ). However, no significant difference was noted in both the number and the length of shoots induced between the various concentrations of agar $\left(\mathrm{F}_{3,133}=2.18, \mathrm{P}=0.105, \mathrm{~F}_{3,133}=0.66, \mathrm{P}\right.$ $=0.578$, respectively for number and length of shoots). Similar results were obtained by Cousineau and Donnelly [35], Ladyman and Girard [36], respectivily in raspberry (Rubus idaeus L.), and cucumber (Cucumis sativus) wherein, increasing agar concentrations from 2.0 $\mathrm{g} / 1$ to $10.0 \mathrm{~g} / \mathrm{l}$ had no significant effect on raspberry micropropagation and no effect of gelling agent on the fresh weight of $C$. sativus somatic embryo tissue. When we analyzed the induced shoot length, we noticed that the agar concentration of $6 \mathrm{~g} / \mathrm{l}$ gave shoots with the highest length. These data were similar to those obtained with Prunus amygdalus L. var. Binazir [37] in which the greatest amount of growth was obtained in the lowest 
$\operatorname{agar}(6 \mathrm{~g} / 1)$ treatment. Increasing concentration of agar to $10 \mathrm{~g} / 1$ reduces Curcuma haritha $\mathrm{L}$. shoot number and length. This may be due to the reduced uptake of mineral nutrients and organic matters, due to higher rigidity of the medium [38]. Therefore, the level of agar in the medium should be such that it minimizes the water loss and allows the good diffusion of nutrient elements. Therefore, the agar concentration of $6 \mathrm{~g} / \mathrm{l}$ was retained in the subsequent experiments.

\subsection{Combination of Factor Shaving a Significant Influence on Shoot Induction}

The adjustment on a full quadratic surface model on the arcsin-transformed mean percentage of explants showing shoot growth resulted in a very highly significant linear effect of minerals and sucrose concentrations $\left(\mathrm{F}_{2,145}=12.45, \mathrm{P}<0.001\right)$, a very highly significant quadratic effect of minerals and BAP concentrations $\left(\mathrm{F}_{2}\right.$, $\left.{ }_{145}=8.33, \mathrm{P}<0.001\right)$ and a significant sucrose and BAP concentrations interaction $\left(\mathrm{F}_{1,145}=4.67, \mathrm{P}=0.032\right)$. The adjustment of this model was satisfying as shown by the non-significant lack-of-fit test $\left(\mathrm{F}_{4,141}=0.394, \mathrm{P}=0.813\right)$. The Figure 3 shows the contour plots of the response based on this adjusted model. Each panel shows the effect of mineral and sucrose concentrations on shoot induction, for each level of the BAP concentration. It is easily noticeable that the maximal response is obtained by the combination of low values of mineral concentrations with high values of sucrose and BAP concentrations, corresponding to $3 / 2$ strength of MS medium, 35 $\mathrm{g} / \mathrm{l}$ sucrose and $1 \mathrm{mg} / \mathrm{l}$ BAP. Following the fitted response surface model, the expected percentage of explants showing shoot growth is $71.8 \%$ for this optimal medium. As this combination of factors was not tested by the BoxBenhken design, 30 new explants were cultured on the designated optimal medium. The explants cultured on the optimal medium had better potential for multiple shoot induction than above media (Figure 2(c)).

On the optimal medium, the percentage of shoot induction was $76.7 \%$, the average number and length of adventitious shoots per responsive explant was respectively $12.26 \pm 6.90$ and $17.13 \pm 4.53 \mathrm{~mm}$. Compared to this optimal medium, the number of shoots per responsive explant was low when the factors were studied alone. For example, the mineral concentration $2 \mathrm{MS}$ was the best mineral concentration to promote high number of shoots alone but, in combination with various concentrations of sucrose and BAP, the best concentration was 3/2 MS. Also, when sucrose was studied alone, the concentration of $25 \mathrm{~g} / \mathrm{l}$ was the best sucrose concentration to promote high number of shoots but in combination with various BAP concentrations and different strengths of MS medium, the best concentration was $35 \mathrm{~g} / \mathrm{l}$. When sucrose and agar were studied alone, the various concentrations of sucrose and agar favour high percentages of shoot induction but give only a low number of shoots per explant. In contrast, with the optimal medium $(3 / 2$ strength of MS medium, $35 \mathrm{~g} / 1$ sucrose, $1 \mathrm{mg} / \mathrm{l} \mathrm{BAP}$ and $6 \mathrm{~g} / \mathrm{l}$ agar), the number of shoots produced per explant was highest. It emerges from the study that the factors that exhibit the highest percentages of shoot induction did not necessarily produced high numbers of shoots per explants. Similar observations had also been reported by Brar et al. [39] in Vigna unguiculata (L.) Walp. where the genotypes that produced high numbers of shoots per explant did not necessarily exhibit the highest percentage of shoot induction. The results of the study show an interaction between the plant growth regulators, sucrose and the composition of the basal medium. Similar results were reported by Vandemoortele et al. [40] in cauliflower wherein shoots propagation was dependent on the interaction between plant growth regulators and high sucrose-to-macronutrients ratio in the medium. An interaction between salt and sucrose concentrations was demonstrated in Lilium auratum Lindl. as optimum dry
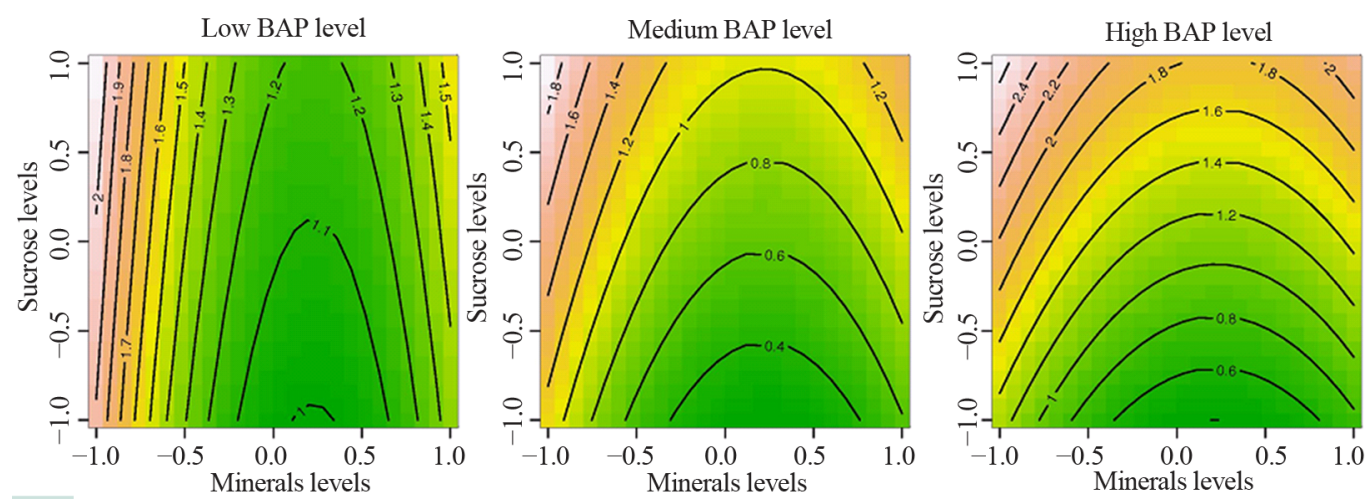

Figure 3. Effect of interaction between minerals, sucrose and BAP concentrations on adventitious shoot induction in C. lanatus oleaginous type. Each value on the contour plot represents the arcsin-transformed mean percentage of explants inducing at least one shoot. 
weight of bulbs could be obtained in either single strength MS + $120 \mathrm{~g} / 1$ sucrose, or double strength MS + $60 \mathrm{~g} / \mathrm{l}$ sucrose [41].

\subsection{Genotypic Response}

Of the four cultivars evaluated for shoot induction, CS and CM cultivars responded favorably. The cultivars showed variable percentages of shoot induction ranging from $54 \%$ to $96 \%$ (Table 3). The highest percentages of shoot induction, $96 \%$ and $76.7 \%$, were obtained with CS and CM cultivars, respectively. The number of shoots produced per explant was significantly different among the four cultivars, ranging from 5.03 to 12.44 shoots per explant, with the highest values in CS (12.44), CM (12.26) and CL (11.93) (Table 3). Cultivars that produced high numbers of shoots per explant did not necessarily exhibit the highest percentages of shoot induction. No significant difference in the length of the induced shoots was noted between cultivars. Similar results have been reported in various Cucurbitaceae species by Srivastava et al. [42] and Compton and Gray [43]. Those authors noted that genotype strongly influenced micropropagation. In another study conducted by Abrie and van Staden [44] on five Cucurbitaceae species, Cucurbita maxima Duch. cv. A-line, C. maxima cv. Chicago Warted and C. pepo L. cv Rolet, did not form shoots on any of culture media tested. Only Cucumis melo L. cv Hales Best 36 and Cucumis sativus cv Ashley formed shoots. Unlike, in the present work all tested genotypes react to shoot induction. Although the percentages of shoot induction are different, they are beyond 50\%, showing a good reaction to optimal medium. The cultivars $\mathrm{CS}, \mathrm{CM}$ and $\mathrm{CL}$ belonging to the same cultigroup showed no significant differences both in the number and the length of the induced shoots. The difference is observed only for the genotype CT. Although the genotype CT was characterized by the lowest number of shoots per explant, this result is higher ( 5 shoots per explant) than those obtained by Niedz et al. [45] with Cucumis melo cv. Hale of Best Jumbo, by Ananthakrishnan et al. [46] with Cucurbita pepo, by Han et al. [47] with Lagenaria siceraria Standl and by Krug et al. [48] with Citrullus lanatus cv. Crimson sweet. These authors obtained a number ranging from 1 to 4 shoots per explant with a percentage of shoot induction from $21 \%$ to $63 \%$ after 4 weeks of culture. The optimal medium in the present work, regardless of the genotype, allows the induction of shoots with length beyond that required (minimum $15 \mathrm{~mm}$ ) by Compton et al. [49] for a good rooting of shoots.

\subsection{Rooting, Acclimatization and Transplanting to Soil}

Rooting of shoots was achieved in the rooting medium
(Figure 2(d)). Percentages of root induction varied according to cultivars, ranging from $88 \%$ to $96 \%$, with the highest values in cultivar CT $(96 \%)$, followed by the cultivars CM and CL (94\%). The percentage of acclimatized plants ranged from $48 \%$ to $70 \%$. Plantlets obtained from cultivar CL showed the highest percentage of acclimatization (70\%). Plantlets obtained from cultivar CS showed on the contrary the lowest acclimatization percentage (48\%). The results obtained with the rooting medium, for each cultivar, were similar to those obtained with watermelon (Citrullus lanatus) by Compton et al. [49] who noted that shoots of at least $15 \mathrm{~mm}$ length, rooted easily. Previous or former protocols for shoot micropropagation from Cucurbitaceae cotyledon segments are based on three or four culture phases $[2,19,20,48]$. Unlike, in the present study, regenerated plants were obtained using a two phases procedure (i.e., shoot induction phase followed by rooting phase), reducing micropropagation time and optimizing shoot formation (12 shoots per explant). The equivalent number of shoots per explants was obtained at induction phase in Cucumis melo var. makuwa by Muruganantham et al. [50] with high levels of BAP (2 mg/l BA), but the micropropagation procedure was based on four culture phases. Other studies indicated that elongation phase could be eliminated by modified initial culture medium [51,52]; in these reports authors observed that the same number of shoots regenerated in previous reports could be obtained per explants by using a simple two-step procedure (i.e., shoot proliferation (shoots were repeatedly subcultured for up to three months) followed by root induction). The plantlets from cultivar CL, CM and CT with a length higher than $15 \mathrm{~mm}$ acclimatized easily and showed highest percentage of acclimatization. These results were in accordance with the study of Compton et al. [49,53], indicating a correlation between plantlet length and acclimatization survival.

\subsection{Morphological Evaluation}

C. lanatus oleaginous type plants obtained through micropropagation were transplanted into the fields and compared with seeded plants on the basis of various morphological characters. Figure 4 shows plants acclimatized in the greenhouse and thereafter transplanted into the field where they grew like seeded plants. Analyses of data recorded on each cultivar do not reveal any variations for different morphological traits between the micropropagated plants and the seed-propagated plants as shown in Table 4. Similar absence or lack of morphological variation was reported in the micropropagation of cucumber, Cucumis sativus L. [29]. Bhatia and Ashwath [54] also observed no change in morphological characters between the tissue-cultured and seed-propagated tomato (Lycopersicon esculentum Mill. cv. Red Coat). 


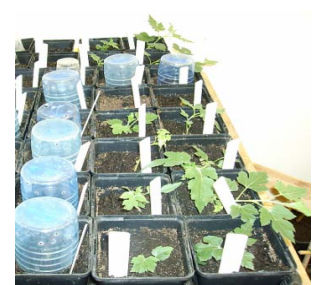

(a)

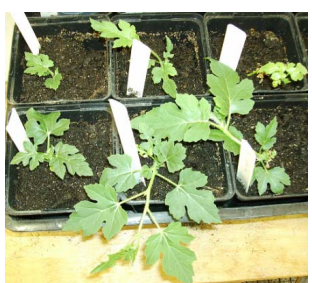

(b)

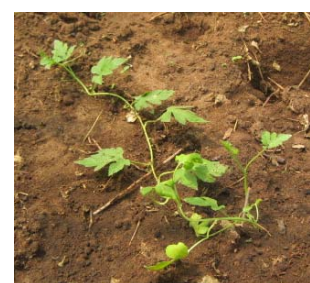

(c)

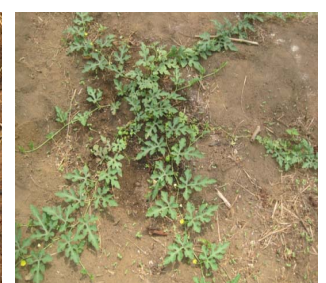

(d)

Figure 4. Plantlet micropropagation in C. lanatus oleaginous type: (a) The removal of lid after acclimatization; (b) Acclimatized plants in the greenhouse; (c) Transplanting of acclimatized plants to field; (d) Acclimatized plant with flowers after transferring to field.

Table 4. Values of eight traits analyzed in plants from seed (control) and in vitro culture for each cultivar of C. lanatus oleaginous type.

\begin{tabular}{|c|c|c|c|c|c|c|c|c|c|c|c|c|}
\hline \multirow[t]{3}{*}{ Characters } & \multicolumn{12}{|c|}{ Cultivars } \\
\hline & \multicolumn{3}{|c|}{$\mathrm{CS}$} & \multicolumn{3}{|c|}{$\mathrm{CM}$} & \multicolumn{3}{|c|}{$\mathrm{CL}$} & \multicolumn{3}{|c|}{$\mathrm{CT}$} \\
\hline & Control & In vitro & $\mathrm{P}$ & Control & In vitro & $\mathrm{P}$ & Control & In vitro & $\mathrm{P}$ & Control & In vitro & $\mathrm{P}$ \\
\hline MF (days) & $46.6 \pm 7.40$ & $46.4 \pm 7.16$ & 0.96 & $44.8 \pm 0.84$ & $43.8 \pm 1.48$ & 0.22 & $39.6 \pm 0.89$ & $39.8 \pm 3.27$ & 0.89 & $40.2 \pm 1.09$ & $39.8 \pm 1.09$ & 0.58 \\
\hline FF (days) & $56.6 \pm 7.44$ & $56.8 \pm 6.94$ & 0.96 & $55.2 \pm 0.84$ & $51.6 \pm 6.11$ & 0.22 & $52.4 \pm 3.29$ & $51.60 \pm 6.17$ & 0.80 & $51.2 \pm 1.79$ & $50.8 \pm 1.30$ & 0.69 \\
\hline MFD (cm) & $2.78 \pm 0.58$ & $2.76 \pm 0.27$ & 0.88 & $3.14 \pm 0.58$ & $3.10 \pm 0.29$ & 0.78 & $2.88 \pm 0.45$ & $2.9 \pm 0.34$ & 0.84 & $2.87 \pm 0.34$ & $2.97 \pm 0.42$ & 0.32 \\
\hline FFD (cm) & $2.89 \pm 0.33$ & $2.90 \pm 0.21$ & 0.88 & $3.17 \pm 0.27$ & $3.18 \pm 0.28$ & 0.89 & $3.24 \pm 0.68$ & $3.22 \pm 0.57$ & 0.90 & $3.07 \pm 0.36$ & $3.17 \pm 0.44$ & 0.32 \\
\hline MFPL (cm) & $2.81 \pm 0.50$ & $2.82 \pm 0.23$ & 0.92 & $3.05 \pm 0.48$ & $3.22 \pm 0.89$ & 0.34 & $3.39 \pm 1.05$ & $3.43 \pm 0.69$ & 0.87 & $3.5 \pm 0.86$ & $3.57 \pm 1.12$ & 0.78 \\
\hline FFPL (cm) & $4.23 \pm 0.76$ & $4.24 \pm 0.70$ & 0.95 & $4.38 \pm 0.82$ & $4.39 \pm 0.88$ & 0.98 & $3.99 \pm 0.60$ & $4.22 \pm 0.59$ & 0.14 & $4.06 \pm 0.61$ & $4.29 \pm 1.14$ & 0.34 \\
\hline $\operatorname{LL}(\mathrm{cm})$ & $12.72 \pm 2.57$ & $12.61 \pm 1.34$ & 0.84 & $13.98 \pm 4.13$ & $13.88 \pm 3.62$ & 0.92 & $14.68 \pm 0.73$ & $14.74 \pm 1.14$ & 0.83 & $14.62 \pm 2.38$ & $14.89 \pm 2.91$ & 0.68 \\
\hline LWI (cm) & $10.60 \pm 2.62$ & $9.80 \pm 1.40$ & 0.14 & $10.97 \pm 2.37$ & $10.99 \pm 1.46$ & 0.96 & $11.43 \pm 0.85$ & $11.47 \pm 2.11$ & 0.92 & $11.34 \pm 1.64$ & $11.71 \pm 0.95$ & 0.24 \\
\hline
\end{tabular}

For the acronyms, see Table 2.

However, such morphological markers have the limitations of being dependent on environmental factors and representing partially the genetic constitution of the plant [55]. Use of molecular markers is therefore helpful to complete the genetic evaluation.

\subsection{Genetic Stability Assessment}

From the five screened primer combinations for the AFLP analysis, four combinations generated a multiloci DNA fingerprinting with a total of $605,781,605,737$ fragments respectively for genotypes CS, CM, CL and CT. The highest number of DNA fragments $(29,20$, and 26 for genotype CS, CL, and CT respectively) was obtained with $\mathrm{E}_{\mathrm{AAG}}-\mathrm{M}_{\mathrm{CAG}}$, whereas the lowest number of bands $(12,11$, and 12 for genotype CS, CL, and CT respectively) was produced with $\mathrm{E}_{\mathrm{AAG}}-\mathrm{M}_{\mathrm{CAT}}$. The AFLP assays generated 18,18, 17 and 14 bands per primer combination, on average respectively for genotypes CS, $\mathrm{CM}, \mathrm{CL}$ and $\mathrm{CT}$, and no polymorphism was detected between the micropropagated plants and the mother plant providing the analyzed cotyledon explants (Figure 5). AFLP analyses cover different regions of DNA and gen- erate large numbers of bands, thus representing a random-sampling of the genome. The absence of polymorphism in all the loci for each genotype indicates that $C$. lanatus oleaginous type plants obtained through direct organogenesis are genetically stable in the assessed genome regions. Similar results were obtained using AFLP markers in Humulus lupulus L. [56], Pisum sativum L. [57] and Arachis retusa L. [58] and also using markers RAPD and ISSR in Prunus dulcis (Miller) DA Webb [59] and Tigridia pavonia (Lf) DC [60]. While some investigators reported absence of in vitro-induced variation in a number of plant species, significant polymorphism rates were found in plants micropropagated via somatic embryogenesis [61], calluses [62] and direct organogenesis [63]. This apparent discrepancy can be related to different factors, including the micropropagation procedure, genotype and number of primers used in the amplification reactions. The absence of somaclonal variation observed in the present study could be attributed to the fact that the shoots were induced directly without a callus phase and subculture. Soniya et al. [64] have reported that commonness of genetic variation in Lycopersicon 

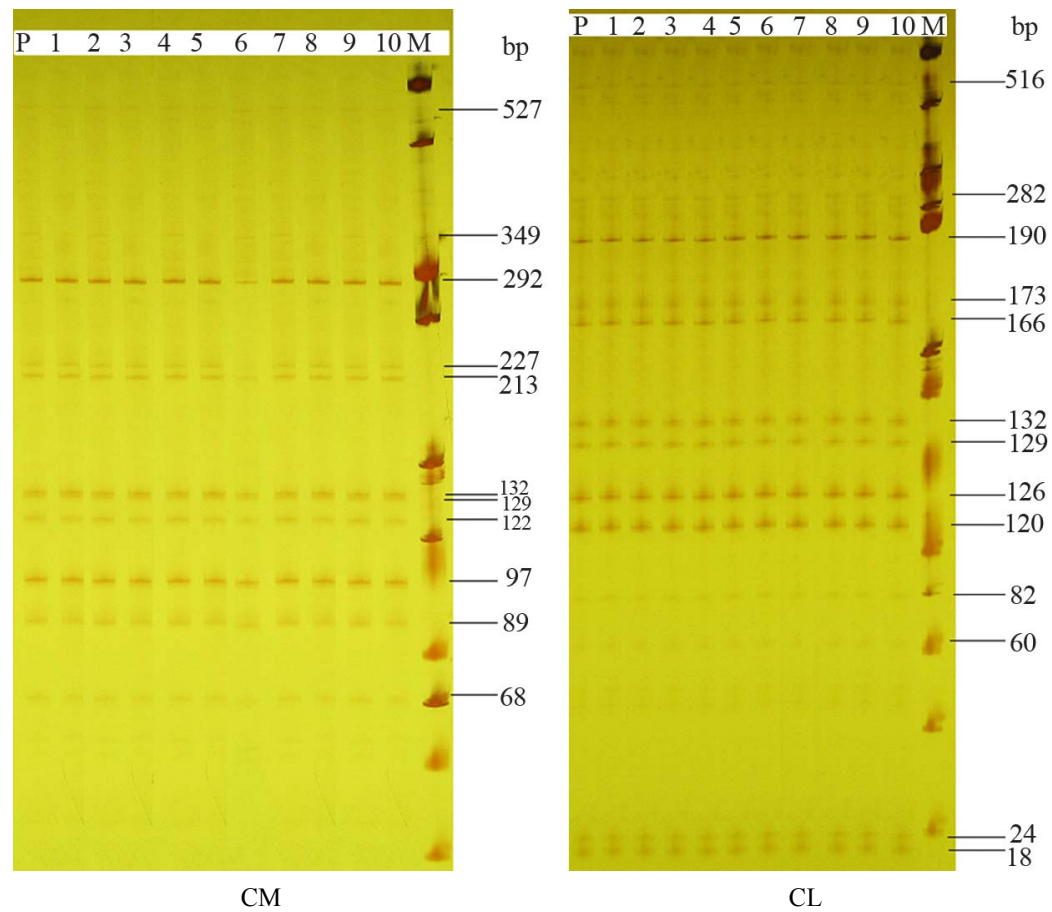

Figure 5. AFLP profiles of 10 regenerated plantlets (lane 1 to 10 ) and the mother plant (lane $\mathrm{P}$ ) for two cultivars of $C$. lanatus oleaginous type (CM and $\mathrm{CL}$ ) using primer pair E-AAG/M- CTC. For each cultivar identical patterns were observed in the 11 tested plants.

esculentum Mill cv. Sakthi micropropagated plants could be attributed to the callus phase. However, no genetic marker can provide absolute evidence that somaclonal variation has not occurred in culture. Therefore, it is important to choose micropropagation procedures that minimize induced variation.

\section{CONCLUSION}

The present study describes an efficient protocol to optimize cucurbits oleaginous type micropropagation. Shoot induction was mostly affected by the interaction between plant growth regulators, sucrose and minerals levels. The optimal medium found is an effective micro propagation medium for cucurbits oleaginous type because no somaclonal variation was observed among the micropropagated plants. The new protocol developed in this study can be extended to other relative species and cultivars of cucurbits oleaginous type.

\section{ACKNOWLEDGEMENTS}

Fellowship to the first author was awarded by Agence Universitaire de la Francophonie (AUF), Abidjan (Côte d'Ivoire).

\section{REFERENCES}

[1] Gusmini, G., Wehner, T.C. and Jarret, R.L. (2004) Inheri- tance of Egusi seed type in watermelon. Journal of Heredity, 95, 268-270. doi:10.1093/jhered/esh031

[2] Gnamien, Y.G., Zoro Bi, I.A., Djè, Y., Toussaint, A. and Baudoin, J.P. (2010) Determination of a suitable protocol for indigenous oilseed cucurbits plant regeneration. Tropicultura, 28, 217-225.

[3] Kortse, P.A., Oladiran, J.A. and Msaakpa, T.S. (2012) Effect of season and fruit size on the quality of "egusi" melon [Citrullus lanatus (Thunb) Matsum and Nakai] seed. ARPN Journal of Agricultural and Biological Science, 7, 110-116.

[4] Zoro Bi, I.A., Koffi, K.K. and Djè, Y. (2003) Caractérisation botanique et agronomique de trois espèces de cucurbites consommées en sauce en Afrique de l'Ouest: Citrullus sp., Cucumeropsis mannii Naudin et Lagenaria siceraria (Molina) Standl (Botanical and agronomical characterization of three species of cucurbit consumed as sauce in west Africa: Citrullus sp., Cucumeropsis mannii Naudin and Lagenaria siceraria (Molina) Standl.). Biotechnolgy, Agronomy, Society and Environment, 7, 189-199.

[5] Schippers, R. (1997) Egusi. In: IPGRI, Ed., African Indigenous Vegetables, IPGRI/NRI, IPGRI Workshop Proceeding, Limbe, 93-112.

[6] Zoro Bi, I.A., Koffi, K.K., Djè, Y., Malice, M. and Baudoin, J.P. (2006) Indigenous cucurbits of Côte d'Ivoire. Review of their genetic resources. Science \& Nature, 3, $1-9$.

[7] Achu, M.B., Fokou, E., Tchiengang, Fotso, M. and Mbiapo, F.T. (2005) Nutritive value of some Cucurbitaceous oilseeds from different regions of Cameroon. African 
Journal of Biotechnology, 4, 1329-1334.

[8] Loukou, A.L., Gnakri, D., Djè, Y., Kippré, A.V., Malice, M., Baudoin, J.P. and Zoro Bi, I.A. (2007) Macronutrient composition of three cucurbit species cultivated for seed consumption in Côte d'Ivoire. African Journal of Biotechnology, 6, 529-533.

[9] Dalziel, J.M. (1937) The useful plants of west tropical Africa. The Crown Agents for the Colonies, London.

[10] Maggs-Kölling, G.L. and Christiansen, J.L. (2003) Variability in Namibian landraces of watermelon (Citrullus lanatus). Euphytica, 132, 251-258. doi:10.1023/A:1025053331528

[11] Minsart, L.-A., Zoro Bi, I.-A., Djè, Y., Baudoin, J.-P., Jacquemart, A.-L. and Bertin, P. (2011) Set up of simple sequence repeat markers and first investigation of the genetic diversity of West-African watermelon (Citrullus lanatus ssp. vulgaris oleaginous type). Genetic Resources and Crop Evolution, 58, 805-814. doi:10.1007/s10722-010-9617-x

[12] Obiagwu, C.J. and Odiaka, N.I. (1995) Fertilizer schedule for yield of fresh fluted pumpkin (Telfairia occidentalis) grown in lower Benue river basin of Nigeria. Indian Journal of Agricultural Sciences, 65, 98-101.

[13] Ndabalishye, I. (1995) Agriculture vivrière ouest-africaine à travers le cas de la Côte d'Ivoire (West African food crops through the case of Côte d'Ivoire). IDESSA, Bouaké, 383.

[14] Dudu, P., Lale, N.E.S. and Okiwelu, S.N. (1996) Susceptibility of three physical forms of three oilseeds Oryzaephilus mercator and the effects of infestation on seed quality. Postharvest Biology and Technology, 7, 277-283. doi:10.1016/0925-5214(95)00043-7

[15] Djè, Y., Kouonon, L.C., Zoro Bi, I.A., Gnamien, Y.G. and Baudoin, J.P. (2006) Étude des caractéristiques botaniques, agronomiques et de la biologie florale du melon africain (Cucumis melo L. var. agrestis Naudin, Cucurbitaceae) (Study of the botanical, agronomic characteristics and the floral biology of the African melon (Cucumis melo L. var. agrestis Naudin, Cucurbitaceae). Biotechnolgy, Agronomy, Society and Environment, 10, 109-119.

[16] Nerson, H. (1991) Fruit age and seed extraction procedures affect germinability of cucurbit seeds. Seed Science Technology, 19, 185-195.

[17] Nerson, H. (2002) Effects of seed maturity, extraction practices and storage duration on germinability in watermelon. Scientia Horticulturae, 93, 245-256. doi:10.1016/S0304-4238(01)00332-6

[18] Pitrat, M. (2008) Melon. In: Prohens, J. and Nuez, F., Eds., Vegetables I: Asteraceae, Brassicaceae, Chenopodicaceae, and Cucurbitaceae. Springer Science+Business Media, LLC, New York, 283-315.

[19] Suratman, F., Huyop, F. and Parveez, G.K.A. (2009) In vitro shoot regeneration of Citrullus vulgaris schrad (watermelon). Biotechnology, 8, 393-404. doi:10.3923/biotech.2009.393.404

[20] Choi, J.Y., Shin, Y.S., Chung, Y.S. and Hyung, N.I. (2012) An efficient selection and regeneration protocol for Agrobacterium-mediated transformation of oriental melon
(Cucumis melo L. var. makuwa). Plant Cell, Tissue and Organ Culture, 110, 133-140. doi:10.1007/s11240-012-0137-6

[21] Chuang, S.J., Chen, C.L., Chen, J.J., Chou, W.Y. and Sung, J.M. (2009) Detection of somaclonal variation in micro-propagated Echinacea purpurea using AFLP marker. Scientia Horticulturae, 120, 121-126. doi:10.1016/j.scienta.2008.09.020

[22] De la Puente, R., González, A.I., Ruiz, M.L. and Polanco, C. (2008) Somaclonal variation in rye (Secale cereale L.) analyzed using polymorphic and sequenced AFLP markers. In Vitro Cellular and Developmental Biology — Plant, 44, 419-426. doi:10.1007/s11627-008-9152-Z

[23] Murashige, T. and Skoog, F. (1962) A revised medium for rapid growth and bioassays with tobacco tissue cultures. Physiologia Plantarum, 15, 473-497. doi:10.1111/j.1399-3054.1962.tb08052.x

[24] Box, G. and Behnken, D. (1960) Some new three level designs for the study of quantitative variables. Technometrics, 2, 455-475. doi:10.1080/00401706.1960.10489912

[25] Koffi, K.K., Anzara, G.K., Malice, M., Djè, Y., Bertin, P., Baudoin, J.-P. and Zoro Bi, I.A. (2009) Morphological and allozyme variation in a collection of Lagenaria siceraria (Molina) Standl. from Côte d'Ivoire. Biotechnology, Agronomy, Society and Environment, 13, 257-270.

[26] Lacape, J.M., Dessauw, D., Rajab, M., Noyer, J.L. and Hau, B. (2007) Microsatellite diversity in tetraploid Gossypium germplasm: Assembling a highly informative genotyping set of cotton SSRs. Molecular Breeding, 19, 45-58. doi:10.1007/s11032-006-9042-1

[27] Chalhoub, B.A., Thibault, S., Laucou, V., Rameau, C., Hofte, H. and Cousin, R. (1997) Silver staining and recovery of AFLP TM amplification products on large denaturing polyacrylamide gels. Biotechniques, 22, 216-220.

[28] Dagnelie, P. (1998) Theoretical and applied statistics Volume 2: Statistical inference for one and two dimensions. De Boeck \& Larcier, Paris et Bruxelles, 508.

[29] Plader, W., Malepszy, S., Burza, W. and Rusinowski, Z. (1998) The relationship between the regeneration system and genetic variability in the cucumber (Cucumis sativus L.). Euphytica, 103, 9-15. doi:10.1023/A:1018359726626

[30] Zhang, Y., Zhou, J., Wu, T. and Cao, J. (2008) Shoot regeneration and the relationship between organogenic capacity and endogenous hormonal contents in pumpkin. Plant Cell Tissue and Organ Culture, 93, 323-331. doi:10.1007/s11240-008-9380-2

[31] Canli, F.A. and Tian, L. (2008) Regeneration of adventitious shoots from mature stored cotyledons of Japanese plum (Prunus salicina Lind1). Scientia Horticulturae, 120, 64-69. doi:10.1016/j.scienta.2008.09.017

[32] Thomas, T.D. and Sreejesh, K.R. (2004) Callus induction and plant regeneration from cotyledonary explants of ash gourd (Benincasa hispida L.). Scientia Horticulturae, 100, 359-367. doi:10.1016/j.scienta.2003.06.001

[33] Huq, A., Akter, S., Islam, S. and Khan, S. (2012) In vitro micropropagation of pointed gourd (Trichosanthes dioica Roxb.) from shoot tip and nodal segment. Bangladesh 
Journal of Scientific and Industrial Research, 47, $217-$ 222. doi:10.3329/bjsir.v47i2.11457

[34] Lou, H. and Kako, S. (1994) Somatic embryogenesis and plant regeneration in cucumber. HortScience, 29, 906909.

[35] Cousineau, J.C. and Donnelly, D.J. (1991) Adventitious shoot regeneration from leaf explants of tissue cultured and greenhouse-grown raspberry. Plant Cell Tissue and Organ Culture, 27, 249-255. doi:10.1007/BF00157588

[36] Ladyman, J.A.R. and Girard, B. (1992) Cucumber somatic embryo development on various gelling agents and carbohydrate sources. HortScience, 27, 164-165.

[37] Amiri, M.E. (2006) Effect of mineral concentration on in vitro explant growth of almond (Prunus amygdalus var. Binazir). Journal of Applied Horticulture, 8, 62-64.

[38] Bejoy, M., Dan, M. and Anish, N.P. (2006) Factors affecting the in vitro multiplication of the endemic zingiber Curcuma haritha mangaly and sabu. Asian Journal of Plant Science, 5, 847-853. doi:10.3923/ajps.2006.847.853

[39] Brar, M.S., Al-Khayri, J.M., Morelock, L.T.E. and Anderson, E.J. (1999) Genotypic response of cowpea Vigna unguiculata (L.) to in vitro regeneration from cotyledon explants. In Vitro Cellular and Developmental BiologyPlant, 35, 8-12. doi:10.1007/s11627-999-0002-4

[40] Vandemoortele, J.L., Billard, J.E., Boucaud, J. and Gaspar, T. (1999) Evidence for an interaction between basal medium and plant growth regulators during adventitious or axillary shoot formation of cauliflower. In Vitro Cellular and Developmental Biology-Plant, 35, 13-17. doi:10.1007/s11627-999-0003-3

[41] George, E.F., Hall, M.A. and De Kler, G.J. (2008) Plant propagation by tissue culture. 3rd Edition, Springer, Dordrecht.

[42] Srivastava, D.K., Andrianov, V.M. and Piruzian, E.S. (1989) Tissue culture and plant regeneration of watermelon. Plant Cell Reports, 8, 300-302. doi:10.1007/BF00274135

[43] Compton, M.E. and Gray, D.J. (1993) Shoot organogenesis and plant regeneration from cotyledons of diploid, triploid, and tetraploid watermelon. Journal of American Society for Horticultural Science, 118, 151-157.

[44] Abrie, A.L. and Van Staden, J. (2001) Development of regeneration protocols for selected cucurbit cultivars. Plant Growth Regulation, 35, 263-267. doi:10.1023/A:1014415419158

[45] Niedz, R.P., Smith, S.S., Dunbar, K.B., Stephens, C.T. and Murakishi, H.H. (1989) Factors influencing shoot regeneration from cotyledonary explants of Cucumis melo. Plant Cell Tissue and Organ Culture, 18, 313-319. doi:10.1007/BF00043400

[46] Ananthakrishnan, G., Xia, X., Elman, C., Singer, S., Paris, H.S., Gal-On, A. and Gaba, V. (2003) Shoot production in squash (Cucurbita pepo) by in vitro organogenesis. Plant Cell Reports, 21, 739-746.

[47] Han, J.S., Oh, D.G., Mok, I.G., Park, H.G. and Kim, C.K. (2004) Efficient plant regeneration from cotyledon explants of bottle gourd (Lagenaria siceraria Standl.). Plant Cell Reports, 23, 291-296. doi:10.1007/s00299-004-0846-3

[48] Krug, M.G.Z., Stipp, L.C.L., Rodriguez, A.P.M. and Mendes, B.M.J. (2005) In vitro organogenesis in watermelon cotyledons. Pesquisa Agropecuária Brasileira, 40, 861-865. doi:10.1590/S0100-204X2005000900004

[49] Compton, M.E., Gray, D.J. and Gaba, V.P. (2004) Use of tissue culture and biotechnology for the genetic improvement of watermelon. Plant Cell Tissue and Organ Culture, 77, 231-243. doi:10.1023/B:TICU.0000018428.43446.58

[50] Muruganantham, M., Ganapathi, A., Selvaraj, N., Anand, R.P., Vasudevan, A. and Vengadesan, G. (2002) Adenine sulphate and L-glutamine enhance multiple shoot induction from cotyledon explants of melon (Cucumis melo L. cv. Swarna). Cucurbit Genetics Cooperative Report, 25, 22-24.

[51] Compton, M.E. and Gray, D.J. (1992) Micropropagation as a means of rapidly propagating triploid and tetraploid watermelon. Proceedings of the Florida State Horticultural Society, 105, 352-354.

[52] Compton, M.E., Gray, D.J. and Elmstrom, G.W. (1993) A simple protocol for micropropagating diploid and tetraploid watermelon using shoot-tip explants. Plant Cell Tissue and Organ Culture, 33, 211-217. doi:10.1007/BF01983236

[53] Compton, M.E., Pierson, B.L. and Staub, J.E. (2001) Micropropagation for recovery of Cucumis hystrix. Plant Cell Tissue and Organ Culture, 64, 63-67. doi:10.1023/A:1010645206280

[54] Bhatia, P. and Ashwath, N. (2004) Comparative performance of micropropagated and seed-grown tomato plants. Biologia Plantarum, 48, 625-628. doi:10.1023/B:BIOP.0000047165.52040.d0

[55] Mandal, A.B., Maiti, A., Cowdhury, B. and Elanchezhian, R. (2001) Isoenzyme markers in varietal identification of banana. In Vitro Cellular and Developmental BiologyPlant, 37, 599-604. doi:10.1007/s11627-001-0105-Z

[56] Peredo, E.L., Revilla, M.Á. and Arroyo-García, R. (2006) Assessment of genetic and epigenetic variation in hop plants regenerated from sequential subcultures of organogenic calli. Journal of Plant Physiology, 163, 10711079. doi:10.1016/j.jplph.2005.09.010

[57] Smýkal, P., Valledor, L., Rodríguez, R. and Griga, M. (2007) Assessment of genetic and epigenetic stability in long-term in vitro shoot culture of pea (Pisum sativum L.). Plant Cell Reports, 26, 1985-1998. doi:10.1007/s00299-007-0413-9

[58] Gagliardi, R.F., Hanai, L.R., Pacheco, G., Oliveira, C.A., Carneiro, L.A., Montenegro, V.J.F., Mansur, E. and Vieira, M.L.C. (2007) Assessment of genetic stability among in vitro plants of Arachis retusa using RAPD and AFLP markers for germplasm preservation. Journal of Integrative Plant Biology, 49, 307-312. doi:10.1111/j.1744-7909.2007.00402.x

[59] Sarmento, D., Martins, M. and Oliveira, M.M. (2005) Evaluation of somaclonal variation in almond using RAPD and ISSR markers. Options Méditerranéennes, 63, 391-395. 
[60] Piña-Escutia, J.L., Vázquez-García, L.M. and Arzate-Fernández, A.M. (2010) In vitro regeneration and genetic fidelity of Tigridia pavonia (L.f.) DC. Electronic Journal of Biotechnology, 13, 1-7. doi:10.2225/vol13-issue1-fulltext-1

[61] Popescu, C.F., Falk, A. and Glimelius, K. (2002) Application of AFLPs to characterize somaclonal variation in anther-derived grapevines. Vitis, 41, 177-182.

[62] Polanco, C. and Ruiz, M.L. (2002) AFLP analysis of somaclonal variation in Arabidopsis thaliana regenerated plants. Plant Science, 162, 817-824. doi:10.1016/S0168-9452(02)00029-8

[63] Kumar, M.B., Barker, R.E. and Reed, B.M. (1999) Morphological and molecular analysis of genetic stability in micropropagated Fragaria x Ananassa cv. pocahontas. In Vitro Cellular and Developmental Biology-Plant, 35, 254-258. doi:10.1007/s11627-999-0088-8

[64] Soniya, E.V., Banerjee, N.S. and Das, M.R. (2001) Genetic analysis of somaclonal variation among callus-derived plants of tomato. Current Science, 80, 1213-1215. 